Egyptian Journal of Aquatic Biology \& Fisheries

Zoology Department, Faculty of Science,

Ain Shams University, Cairo, Egypt.

ISSN $1110-6131$

Vol. 24(3): 109 - 124 (2020)

www.ejabf.journals.ekb.eg

\title{
Study of the physico-chemical quality of the Groundwater in the Sidi Taibi,
} Kenitra, Morocco

\author{
Amina El Yemli ${ }^{1, *}$, Nabyl Berrid ${ }^{2}$, Youssef A. Idrissi ${ }^{2}$, Ali k. Hussein ${ }^{3}$, \\ Fuad Al-Nahmi ${ }^{4}$, Abdelkhalek Ghazi ${ }^{1}$
}

1- Laboratory Environmental Development and Management, Faculty of Letters and Human Sciences, Ibn Tofail University, Kenitra, Morocco

2- 2- Laboratory Agroresource Biotechnology Environment and Quality, Faculty of Sciences, Ibn Tofail University, Kenitra, Morocco.

3- Laboratory Genetics and Biometrics, Faculty of Sciences, Ibn Tofail University, Morocco.

4- Laboratory Geosciences, Faculty of Sciences University Hassan II Casablanca, Marocco.

*Corresponding Author: amina.elyemli@uit.ac.ma

\section{ARTICLE INFO}

\section{Article History:}

Received: Feb. 13, 2020

Accepted: April 26, 2020

Online: May 2020

Keywords:

Well,

Water quality,

Physical parameters

Chemical parameters

Sidi Taibi,

Kenitra,

Marocco

\begin{abstract}
Water is a vital element for humans. It is important to have it in sufficient quality and quantity, thus ensuring a healthy and safe life in the long term. According to a report by the World Health Organization, five million infants and children die each year from diarrheal diseases due to the pollution of food or drinking water. The main objective of this work is to describe the conditions of supplying and distribution of drinking water through an analysis carried out on the freshwater made available to the inhabitants of Sidi Taibi, Kenitra. To do this, we took the sample from eight wells, aiming to describe the physico-chemical characteristics, so we assess the ecotoxicological contamination by the main heavy metals. The physicochemical analysis showed that the wells studied have lower concentrations 1 than the values of the Moroccan standard with the exception of nitrate contents which exceed (55.9-69.2mg/1), concerning the metallic elements, we found only traces. As the parameters follow The conductivity; temperature; $\mathrm{pH}$; cations (calcium, magnesium, potassium, and sodium); anions (chloride, sulfate, bicarbonates, and nitrate); trace elements (Iron, Manganese,..) The consumption of drinking water, a determining factor in the prevention of water-related diseases, should receive special attention. In fact, water intended for human consumption must not contain dangerous chemicals or germs harmful to health.
\end{abstract}

\section{INTRODUCTION}

Sources and groundwater are traditionally the preferred water resources for drinking water, since they are more protected from pollution than surface water However, certain minimum characteristics are required so that they can be used for the production 
of drinking water, which itself claims to meet physico-chemical and biological quality standards. The production of drinking water from natural waters generally requires treatment adapted to the quality parameters to be corrected. In the case of good quality groundwater, a simple treatment step is necessary chlorination. It is well known that the purpose of chlorination is the elimination of pathogenic germs, the oxidation of organic matter and some mineral elements, but also the maintenance of a residual disinfectant capable of ensuring micro-biological protection of waterduring its moving in the distribution network (Claude,1999). However, chemical contamination of drinking water can also cause a number of serious health problems (OMS,2004). Almost 90\% of children deaths caused by diarrheal diseases are directly linked to contaminated water, poor sanitation, or poor hygiene (Santé Canada, 2013). For every child who dies from water-related illnesses, countless others suffering from poor health and lack employment and education opportunities (CAWST, 2013). The objective of our work is to determine and quantify the mineral pollution of the water table of eight wells in the SidiTaibi region. This study considered carrying out physico-chemical analysis in order to characterize the environment (underground spring water) and highlight the parameters that determine the quality of the water. Indeed, global growth in the economy, population density, and infrastructure developments increased stress on the available water and on its quality also, (Darwesh et al. 2019).

\section{MATERIALS AND METHODS}

Our study focused on eight water points irregularly distributed in the study area. The reasons for choosing stations are based on the size of the population served by the chosen water points, risk factors for water pollution such as the lack of drinking water and sanitation networks. Samples are very tight in agricultural and undeveloped areas. All samples were sent to the laboratory in portable coolers at low temperature $\left(4^{\circ} \mathrm{C}\right)$ for measurements and analysis of physicochemical parameters and trace elements. The commune Sidi Taibi is located in the northwest of Morocco, comes under the province of Kénitra .It is bounded from the northwest by the city of Kenitra, northeast by the zone Haddada, from the northwest to the west by the Atlantic Ocean and the commune Bouknadel to the southeast. It is located under the geographical coordinates $34.19^{\circ} 0^{\prime} 0^{\prime \prime}$ North $6.690^{\circ} 0^{\prime} 0 "$ "West. The geographic location of this study area is illustrated in. The spatial representation of the different stations was made using the Arc Gis Arc Map software and are plotted on the topographic map shown in (Fig 1).

The water samples were taken over two seasons winter and summert in the various sites in polyethylene bottles with a capacity of one liter, previously washed with distilled water and then with the sampled water for the analysis of the physic-chemical parameters and for the analysis of trace elements containing nitric acid (2\%). The physico-chemical analysis is determined using optical emission spectroscopy coupled to induced plasma (ICP-OES). 


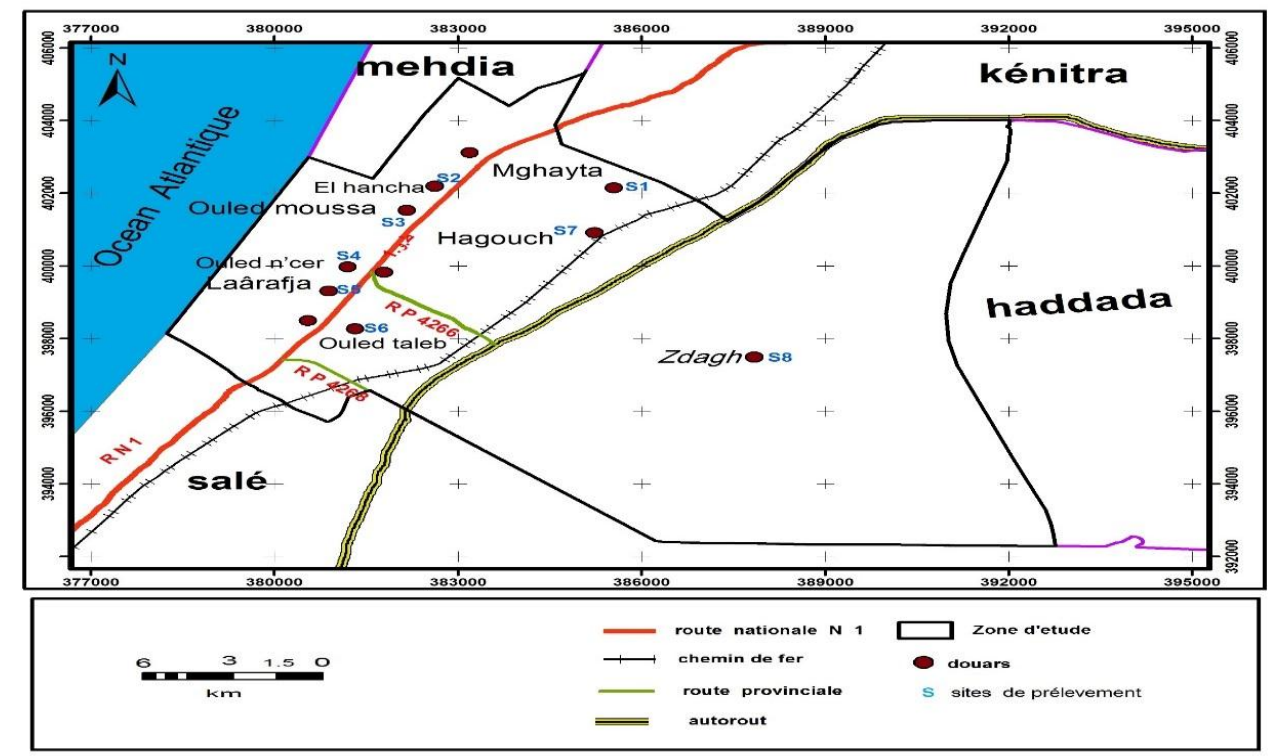

Fig 1: Spatial presentation of the sampling sites located in the study area.

\section{RESULTS AND DISCUSSION}

These are easily measurable parameters that are useful for determining the physical state of water such as temperature, hydrogen potential, and electrical conductivity of water, salinity and the presence of trace metals.

\section{Temperature $\left({ }^{\circ} \mathrm{C}\right)$}

In the study area, the thermal variations are small. The temperature recorded ranges between $15(\mathrm{~S} 3, \mathrm{~S} 7)$ and $16.6^{\circ} \mathrm{C}(\mathrm{S} 6)$ in winter, and between $23.7^{\circ} \mathrm{C}(\mathrm{S} 2)$ and $25.5^{\circ} \mathrm{C}$ (S5) in summer. These results do not show significant seasonal variations for the two seasons (Fig 2).

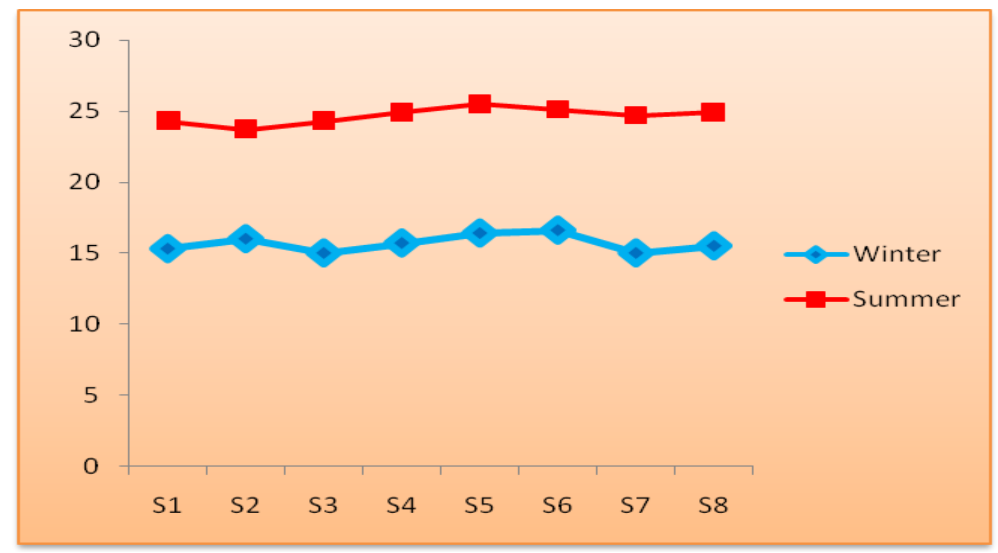

Fig 2: Variation in temperature depending on the records for the two months.

During the study period, the temperature values obtained in almost all of the water points sampled are lower than the (Maximum Allowable Value) $25^{\circ} \mathrm{C}$ of the Moroccan standard relating to the quality of drinking water (El Bouqdaoui et al. 2009; El 
Haissoufi et al. 2011). These recorded results agree with those obtained in previous studies by authors (Ibeda et al. 2013; Kherrati et al. 2015; Akkaoui et al. 2017 ).

\section{Hydrogen potential (pH)}

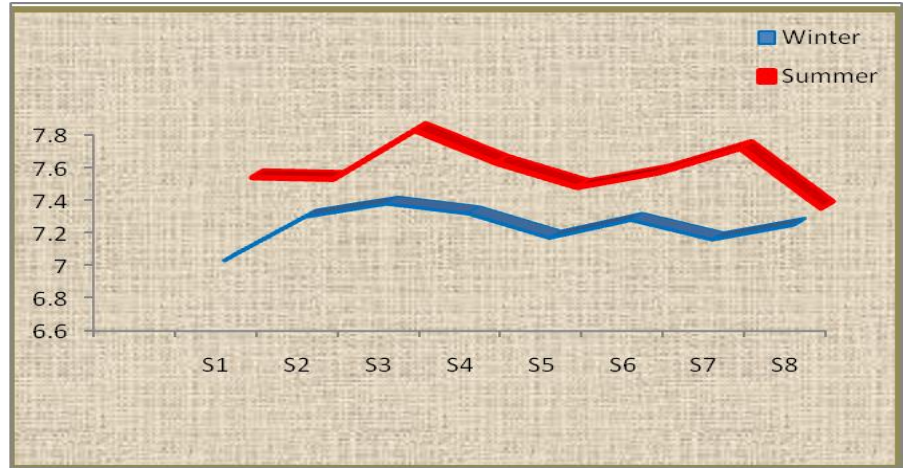

Fig 3: Variation of $(\mathrm{pH})$ depending on therecords for the two months.

In the study area, the $\mathrm{pH}$ values in the waters of the groundwater studied vary from 7 (S1) to 7.35 (S3) during the winter season and from 7.22 (S8) to 7.5 ( S4) during the summer season. These results show no significant variations and no notable seasonal variations for the two seasons (Fig 3). During the study period, the results obtained from the $\mathrm{pH}$ in the majority of sampled water points do not exceed the (MAV) 8.5 of the Moroccan standard recommended for water intended for human consumption (El Ouedghiri et al. 2014 ). The results obtained are consistent with those obtained in previous studies by authors (Nechad et al. 2014; Al-Qawati et al. 2015).

\section{Electrical conductivity (E.C)}

The electrical conductivity measurement is influenced by $\mathrm{pH}$ and temperature. This conductivity is greater when the temperature increases. Standard temperatures are generally taken at 20 or $25^{\circ} \mathrm{C}$ to clarifythe relationship between mineralization and the electrical conductivity of drinking water (Bouabdallah, 2015).

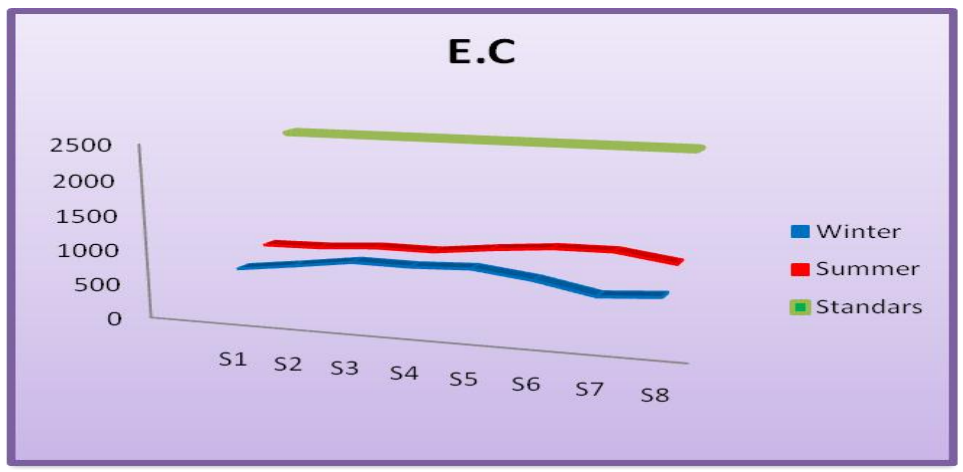

Fig 4: Variation in electrical conductivity as a function of drilling for the two months.

During the year, the electrical conductivity in values measured the groundwater studied during the winter season vary between $737 \mu \mathrm{S} / \mathrm{cm}$ (S7) and $995 \mu \mathrm{S} / \mathrm{cm}$ (S5) and from $958 \mu \mathrm{S} / \mathrm{cm}(\mathrm{S} 1)$ and $1187 \mu \mathrm{S} / \mathrm{cm}(\mathrm{S} 7)$ in summer. These results show a small notable 
seasonal variation (Fig 4).This confirms with the results found in previous studies by the authors' (Nechad et al. 2014 ; kherrati et al. 2015). Furthermore, the comparison of the electrical conductivity in the groundwater of the sidi Taibi aquifer with the Moroccan standard set at $2700(\mu \mathrm{S} / \mathrm{cm})$ (Ben Aakame, 2015). And $2500 \mu \mathrm{S} / \mathrm{cm}$ from $\mathrm{WHO}$ (Laafou et al. 2013). relating to quality drinking water, place that water in the acceptable grid.

4. The differences in the caliber of alkaline water (TAC)

The temporal evolution of this parameter is a real roller-coaster marked by slight fluctuations as well in period of rain as in dry period. Its values oscillate between a minimum $4.44 \mathrm{meq} / \mathrm{L}(\mathrm{S} 1)$ and a maximum $5.52 \mathrm{meq} / \mathrm{L}(\mathrm{S} 6)$ in winter and between 4.63 $\mathrm{meq} / \mathrm{L}(\mathrm{S} 1)$ and $5.62 \mathrm{meq} / \mathrm{L}(\mathrm{S} 6)$ in summer (Fig 5).

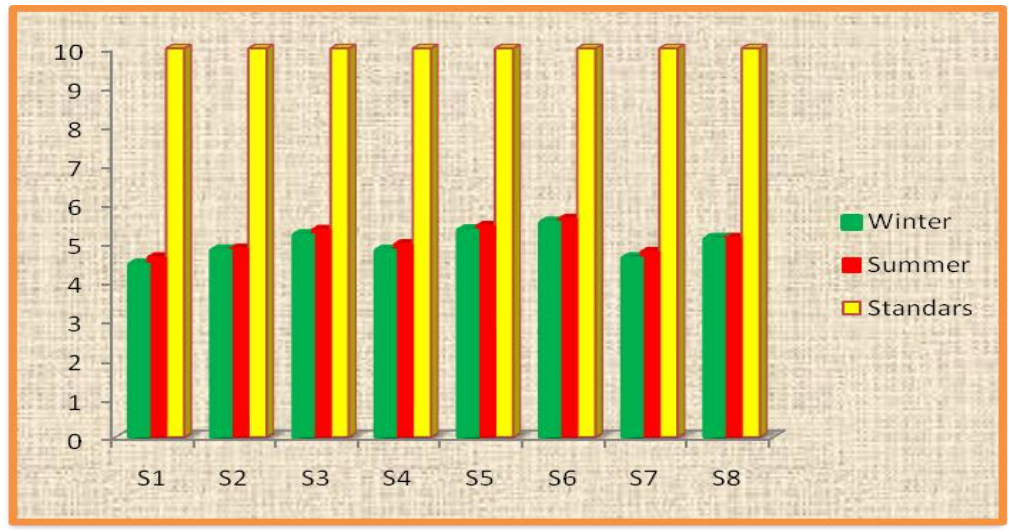

Fig 5: Variation in full alkalimetric titer depending on the boreholes for the two months.

During the study period, the results obtained from measuring the TAC in the groundwater analysis do not show large seasonal variations and comply with the Moroccan standard recommended for water intended for consumption $10 \mathrm{meq} / \mathrm{L}$.

\section{Evolution of metallic trace elements in the waters studied 1. Total iron $\left(\mathrm{Fe}^{2+}\right)$}

During the two seasons, the results recorded in [Total iron] in the groundwater studied do not show large variations while their seasonal variation oscillates between $0 \mathrm{ug} / \mathrm{L}$ (S2, S7) and $10 \mathrm{ug} / \mathrm{L}(\mathrm{S} 1, \mathrm{~S} 3, \mathrm{~S} 4, \mathrm{~S} 5, \mathrm{~S} 6)$ during the winter period and between $6 \mathrm{ug} / \mathrm{L}$ (S8) and $156 \mathrm{ug} / \mathrm{L}$ (S2) (Fig 6).

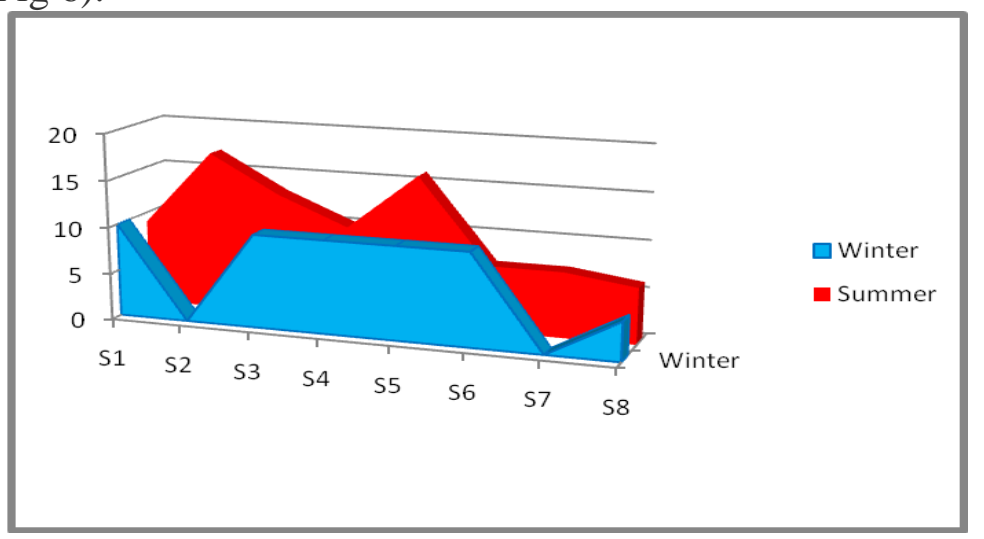

Fig 6: Evolution of total iron in the waters studied. 
The results of the total iron concentrations recorded in the groundwater studied are normal for the two seasons. However, during the study period, these results remain admissible compared to the maximum value $300 \mu \mathrm{g} / \mathrm{L}$ of the Moroccan standard (Laafou et al. 2013), relating to the quality of drinking water. The results obtained in this work are in agreement with those from previous studies carried out by the researchers (Saâdi $\boldsymbol{e t}$ al. 1999; Laafou et al. 2013; Kherrati et al. 2015). On the basis of the results of this parameter obtained during this study, we conclude that the chemical quality of the waters of the sidi Taibi aquifer is admissible.

\section{Manganese $\left(\mathrm{Mn}^{2+}\right)$}

The recorded manganese values $\left[\mathrm{Mn}^{2+}\right]$ are zero in water points $(\mathrm{S} 1, \mathrm{~S} 3, \mathrm{~S} 4, \mathrm{~S} 6, \mathrm{~S} 7)$ and reach a maximum value of $3.2 \mu \mathrm{g} / \mathrm{L}$ in winter and $8 \mu \mathrm{g} / \mathrm{L}$ during the summer period at site level (S5) (Fig7).

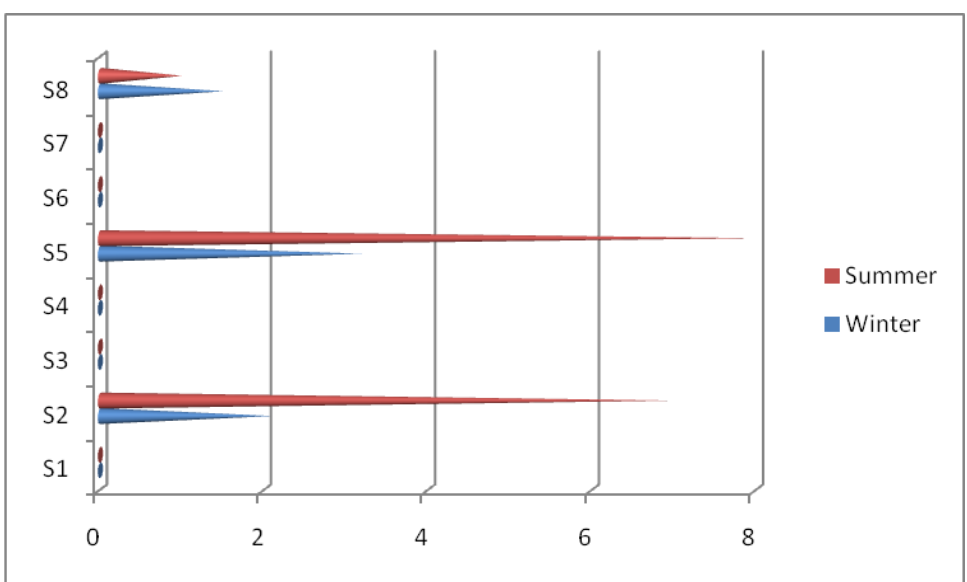

Fig 7: Evolution of manganese in the waters studied.

During this period, the values recorded in manganese in the groundwater studied remain below the maximum admissible value $500 \mu \mathrm{g} / \mathrm{L}$ (Laafou et al. 2013) of the Moroccan standard relating to the quality of drinking water. From there, we conclude that the chemical quality of the controlled groundwater is acceptable in terms of the potability of the water.

\section{Copper $\left(\mathrm{Cu}^{2+}\right)$}

The recorded values of copper $\left[\mathrm{Cu}^{2+}\right]$ in the groundwater studied are between the minimum value $12.61 \mu \mathrm{g} / \mathrm{L}(\mathrm{S} 8)$ and the maximum value $50 \mu \mathrm{g} / \mathrm{L}(\mathrm{S} 4, \mathrm{~S} 5)$ in winter and between the value minimum zero $0.00 \mu \mathrm{g} / \mathrm{L}(\mathrm{S} 1, \mathrm{~S} 2, \mathrm{~S} 3, \mathrm{~S} 4)$ and the maximum value 28 $\mu \mathrm{g} / \mathrm{L}$ (S8) in the summer period. These results do not show seasonal variations during these two seasons (Fig 8). 


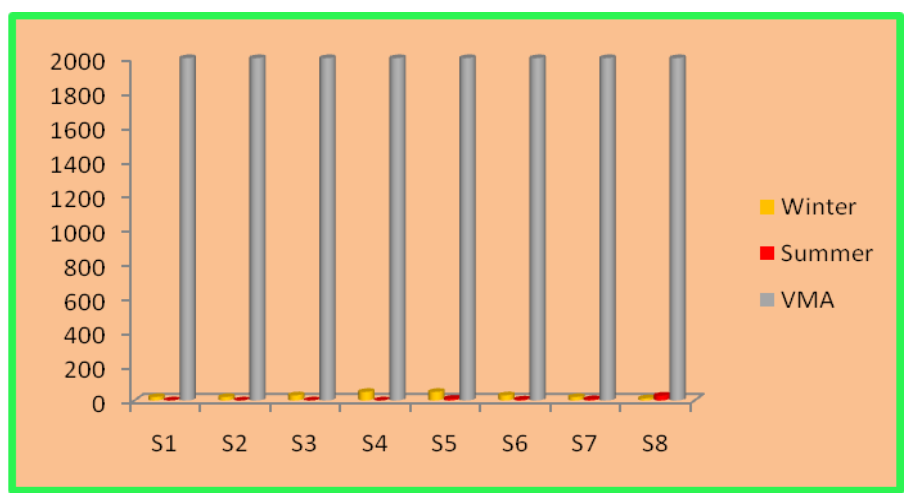

Fig 8: Evolution of copper in the waters studied.

These results are in agreement with those obtained in the previous studies of the two authors (Ibeda et al. 2013;Kherrati et al. 2015). In the study area, the recorded values of copper in groundwater sampled during the study period remain far below the maximum admissible value $2000 \mu \mathrm{g} / \mathrm{L}$ (Taouil et al. 2014), of the Moroccan standard relating to the quality drinking water. Based on the copper element data, we conclude that the chemical quality of the ground water in the Sidi Taibi aquifer is acceptable.

\section{Nickel $\left(\mathrm{Ni}^{2+}\right)$}

In our study, the concentrations of nickel $\left[\mathrm{Ni}^{2+}\right]$ in the groundwater studied vary between $0 \mu \mathrm{g} / \mathrm{L}(\mathrm{S} 3, \mathrm{~S} 4, \mathrm{~S} 5, \mathrm{~S} 6, \mathrm{~S} 8)$ as zero minimum value and $10 \mu \mathrm{g} / \mathrm{L}(\mathrm{S} 1, \mathrm{~S} 2, \mathrm{~S} 7)$ as maximum value in winter period and oscillate between $0 \mu \mathrm{g} / \mathrm{L}(\mathrm{S} 2, \mathrm{~S} 4, \mathrm{~S} 5, \mathrm{~S} 6, \mathrm{~S} 8)$ and $3 \mu \mathrm{g} / \mathrm{L}(\mathrm{S} 1)$ in summer period. These results do not show large seasonal variations during the two seasons (Fig 9).

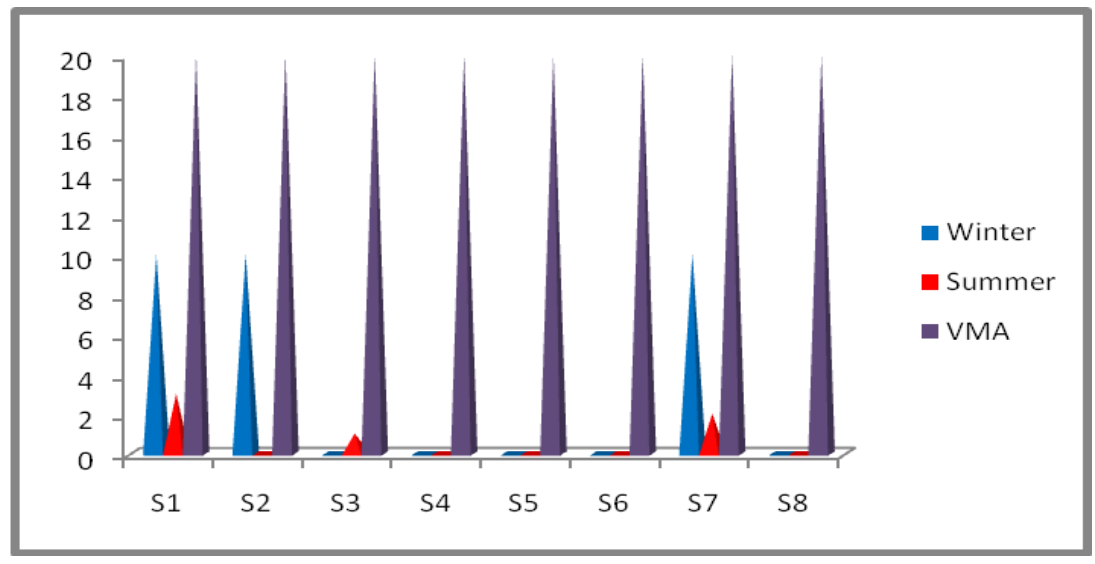

Fig 9: Evolution of the Nikel of the waters studied.

The results obtained during this study agree with those found in previous studies which were carried out by the authors (Bouchouata et al. 2012; Kherrati et al. 2015). During the study period, the nickel concentrations recorded in all of the water points analyzed remain far below the (MAV) $20 \mu \mathrm{g} / \mathrm{L}$ of the Moroccan standard relating to the quality of drinking water and at the guide value $0.2 \mathrm{mg} / \mathrm{L}$ of the Moroccan standard for water suitable for irrigation (Taouil et al. 2014). We conclude that the quality of the groundwater in the Sidi Taibi aquifer is acceptable. 


\section{Zinc $\left(\mathrm{Zn}^{2+}\right)$}

In the study region, the levels of zinc $\left[\mathrm{Zn}^{2+}\right]$ recorded in the groundwater studied range from $0 \mu \mathrm{g} / \mathrm{L}$ (S1) to $40 \mu \mathrm{g} / \mathrm{L}$ (S3, S4) during the winter period and vary by $3 \mu \mathrm{g} / \mathrm{L}$ (S1) to $46 \mu \mathrm{g} / \mathrm{L}(\mathrm{S} 3)$ in the summer period. These results show no significant seasonal variations over the two seasons (Fig 10).

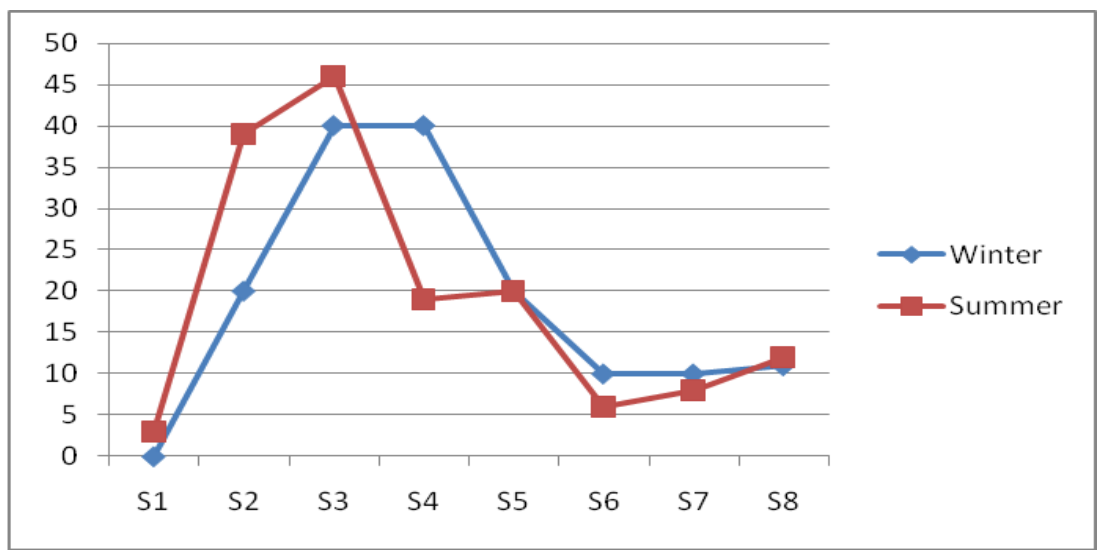

Fig 10: Evolution of Zinc in the waters studied.

They agree with those obtained in previous studies by the researchers (Derwich $\boldsymbol{e t}$ al . 2014; Kherrati et al. 2015). However, these results remain far below the maximum admissible value $3000 \mu \mathrm{g} / \mathrm{L}$ of the Moroccan standard (Laafou et al. 2013) and $5000 \mu \mathrm{g} / \mathrm{l}$ of the WHO (Derwich et al. 2014) relating to the quality of drinking water. So, based on the Zinc parameter results, the water from sidi Taibi aquifer remains usable.

\section{6. lead $(\mathrm{Pb})$}

In the study region, the levels of lead $[\mathrm{Pb}]$ recorded in the groundwater studied range from a zero value $0 \mu \mathrm{g} / \mathrm{L}(\mathrm{S} 1, \mathrm{~S} 2, \mathrm{~S} 3, \mathrm{~S} 4, \mathrm{~S} 5, \mathrm{~S} 6, \mathrm{~S} 7)$ to a maximum value $11,53 \mu \mathrm{g} / \mathrm{L}(\mathrm{S} 8)$ in the winter period and vary from $1 \mu \mathrm{g} / \mathrm{L}$ (S6) to $13 \mu \mathrm{g} / \mathrm{L}(\mathrm{S} 2, \mathrm{~S} 3)$ in the summer period. These results show no significant seasonal variations over the two seasons (Fig 11).

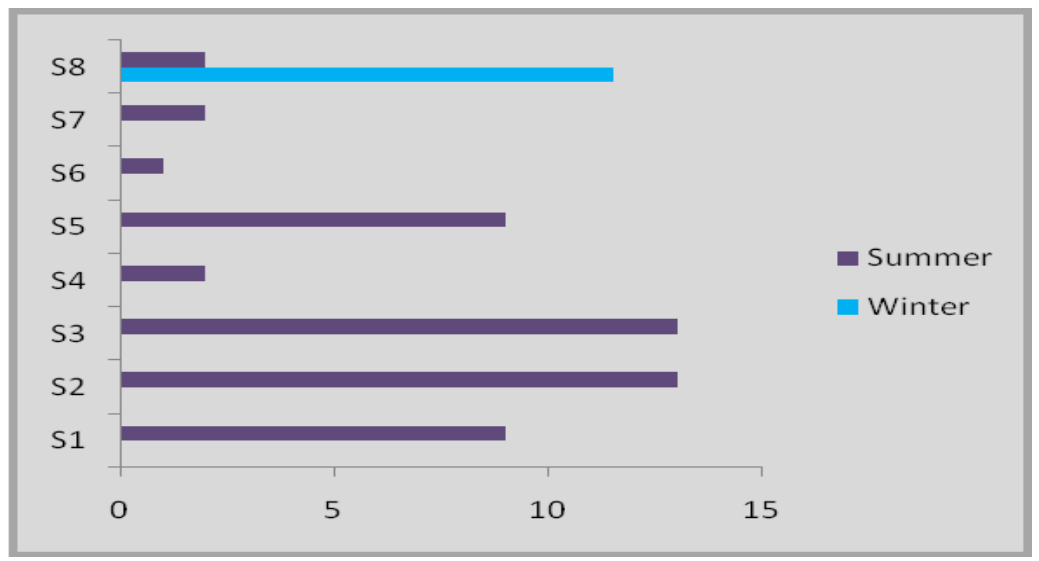

Fig 11: Evolution of Lead the waters studied

From the point of view of toxicity, lead has never been essential for life; on the contrary, it is considered toxic. The presence of lead in groundwater can have a risk for consumers 
since it can cause disorders in the body such as lead poisoning, seizures or even nervous and mental disorders. However, these results remain far below the maximum admissible value $25 \mu \mathrm{g} / \mathrm{L}$ of the Moroccan standard (Derwich et al. 2014). Based on the lead parameter results, the water from the sidi Taibi aquifer remains usable.

\section{Variations in the major ions of the waters studied}

\section{Calcium $\left(\mathrm{Ca}^{2+}\right)$}

During the two seasons, the calcium concentration in the groundwater studied ranges from $148.54 \mathrm{mg} / \mathrm{L}$ (S8) to $256.435 \mathrm{mg} / \mathrm{L}$ (S6) during the winter season and between $72.727 \mathrm{mg} / \mathrm{L}(\mathrm{S} 2, \mathrm{~S} 4)$ and $90.909 \mathrm{mg} / \mathrm{L}(\mathrm{S} 3, \mathrm{~S} 7, \mathrm{~S} 8)$ in the summer period. These results show seasonal variations (Fig 12).

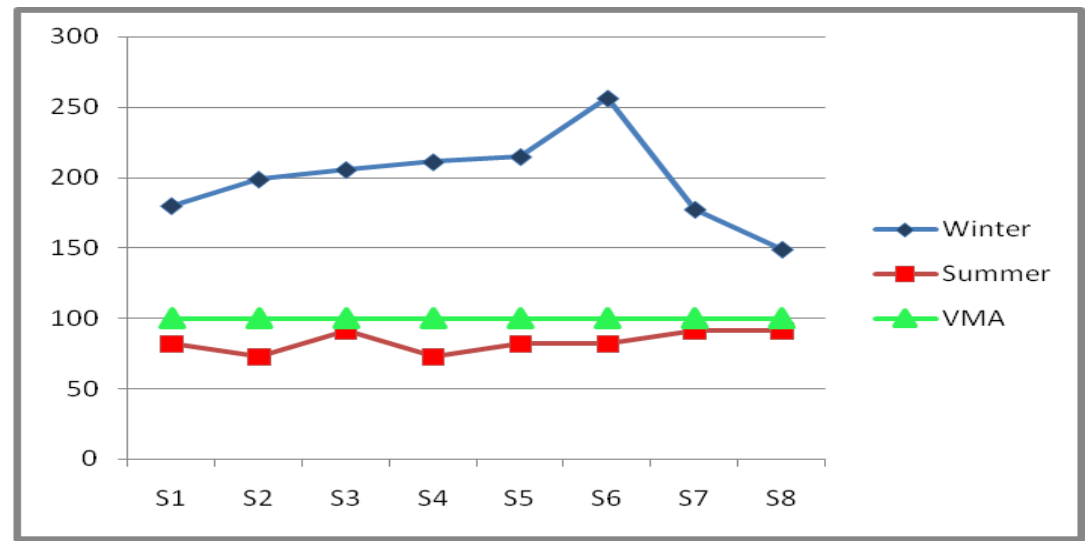

Fig 12: Variations of calcium in the waters studied.

In this study area, the calcium content in the wells studied in general shows significant seasonal variations. The values recorded in calcium in all the points sampled are lower than the guide value fixed by the WHO standards which is $100 \mathrm{mg} / \mathrm{L}$ (Derwich et al . 2013) for the summer month. However, the values found in all of the water points sampled during the winter season are higher than this standard. Consequently, and with regard to this parameter thus discussed, the water quality at the level of the study area is considered acceptable with the exception of the winter season.

\section{Magnesium $\left(\mathrm{Mg}^{2+}\right)$}

The recorded values of magnesium $\left[\mathrm{Mg}^{2+}\right]$ in the groundwater studied range from 4.357 $\mathrm{mg} / \mathrm{L}$ (S8) to $8.55 \mathrm{mg} / \mathrm{L}$ (S6) during the winter season and between $7.492 \mathrm{mg} / \mathrm{L}$ (S6) and 9, $659 \mathrm{mg} / \mathrm{L}(\mathrm{S} 2)$ during the summer season. These results do not show large notable seasonal variations during the two seasons (Fig 13). 


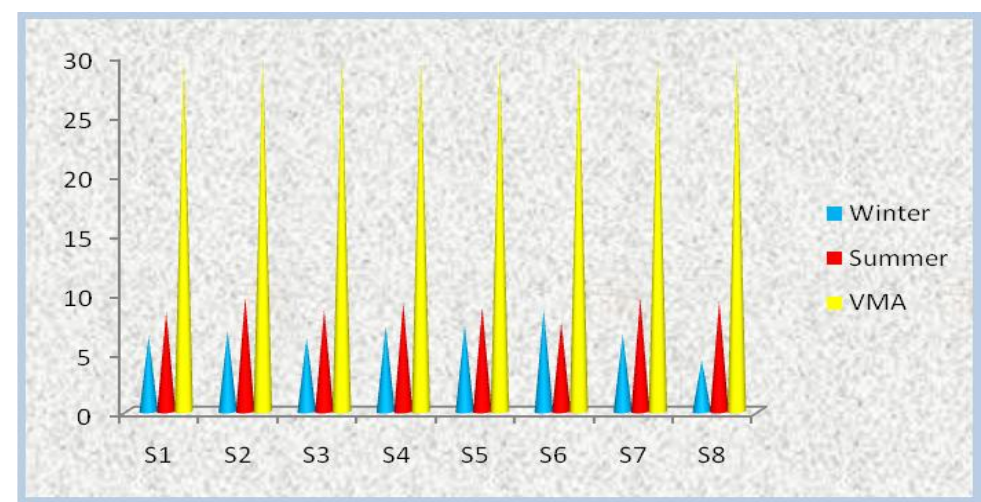

Fig 13: Variations of Magnesium in the waters studied.

During the period of the study, almost all of the water points tested have enormously low magnesium values compared to the maximum admissible value $30 \mathrm{mg} / \mathrm{L}$ of the Moroccan standard relating to the quality of drinking water (Lupton et al. 2008) . Based on these results, the chemical quality of the groundwater in the study area is acceptable.

\section{Potassium $\left(\mathbf{K}^{+}\right)$}

The potassium levels recorded in the waters studied vary in winter from $4.283 \mathrm{mg} / \mathrm{L}$ (S6) to $16.927 \mathrm{mg} / \mathrm{L}$ (S7) and in summer from $1.754 \mathrm{mg} / \mathrm{L}(\mathrm{S} 1, \mathrm{~S} 5, \mathrm{~S} 6, \mathrm{~S} 8)$ to $4.825 \mathrm{mg} / \mathrm{L}$ (S2). These results do not show large seasonal variations (Fig 14).

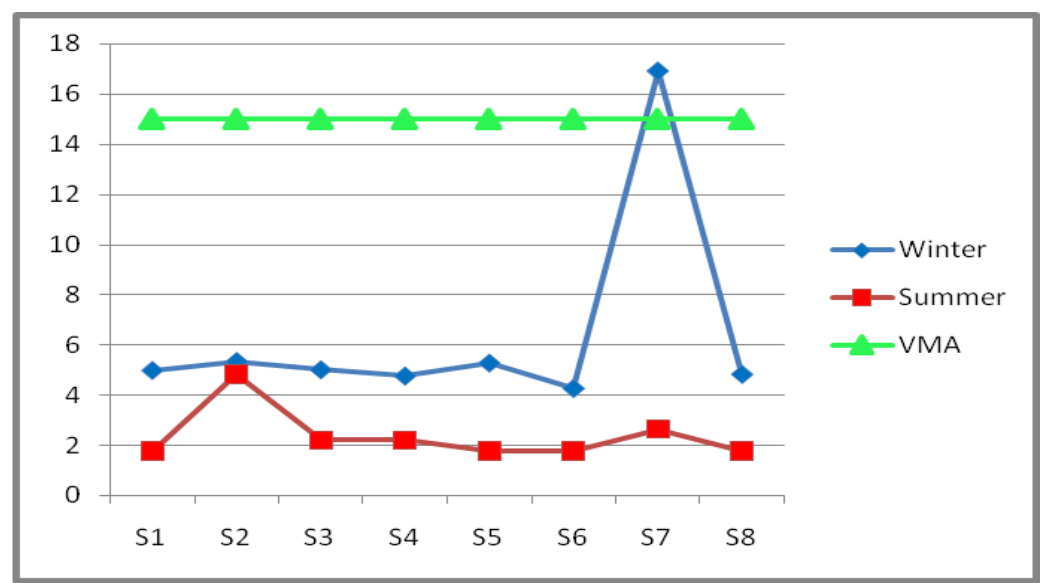

Fig 14: Potassium variations in the waters studied.

During the study period, the values recorded in potassium ions in all the sampled water points are enormously low compared to the maximum admissible value $15 \mathrm{mg} / \mathrm{L}$ of the Moroccan standard relating to the quality of drinking water. Except for site 7 (16.927 $\mathrm{mg} / \mathrm{L}$ ) of the winter season which slightly exceeds the standard. The results of this parameter allow us to conclude that the chemical quality of groundwater in the study region is acceptable in terms of the potability of the water. 


\section{Sodium $\left(\mathrm{Na}^{2+}\right)$}

The sodium values in the groundwater studied vary from $51.811 \mathrm{mg} / \mathrm{L}(\mathrm{S} 1)$ to 118.86 $\mathrm{mg} / \mathrm{L}$ (S6) during the winter season and $18.07 \mathrm{mg} / \mathrm{L}$ (S6) to $26.51 \mathrm{mg} / \mathrm{L}$ (S5) during the summer season. These recorded results show significant seasonal variations (Fig 15).

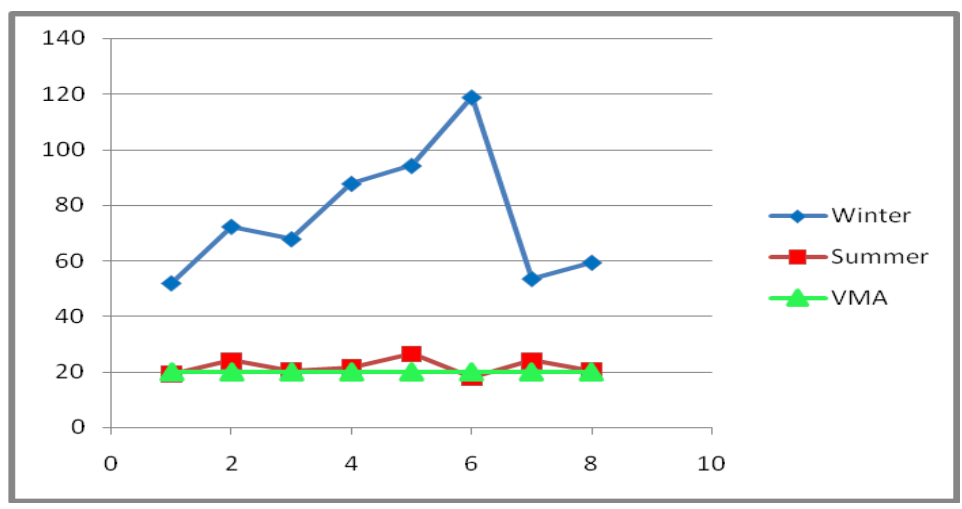

Fig 15: Variations of Sodium in the waters studied.

In the study area, the recorded values of sodium in all the water points studied greatly exceed the guide value $20 \mathrm{mg} / \mathrm{L}$ (Matthess et al. 1994) of the Moroccan standard relating to the quality of drinking water. These results are in agreement with those obtained in the waters of the Mrzuq-Lybie aquifer (Ibeda et al. 2013). Based on the sodium parameter data, we conclude that the water quality at the level of the study region is much degraded.

\section{Chlorides $\left(\mathrm{Cl}^{-}\right)$}

In the study area, the concentrations of chlorides found in controlled groundwater range between $11.6 \mathrm{mg} / \mathrm{L}$ (S3) and $60.5 \mathrm{mg} / \mathrm{L}$ (S6) during the winter period and between 29,6 $\mathrm{mg} / \mathrm{L}$ (S7) and $78.7 \mathrm{mg} / \mathrm{L}(\mathrm{S} 6)$ in the summer period. These results recorded during the two seasons do not show significant seasonal variations (Fig 16).

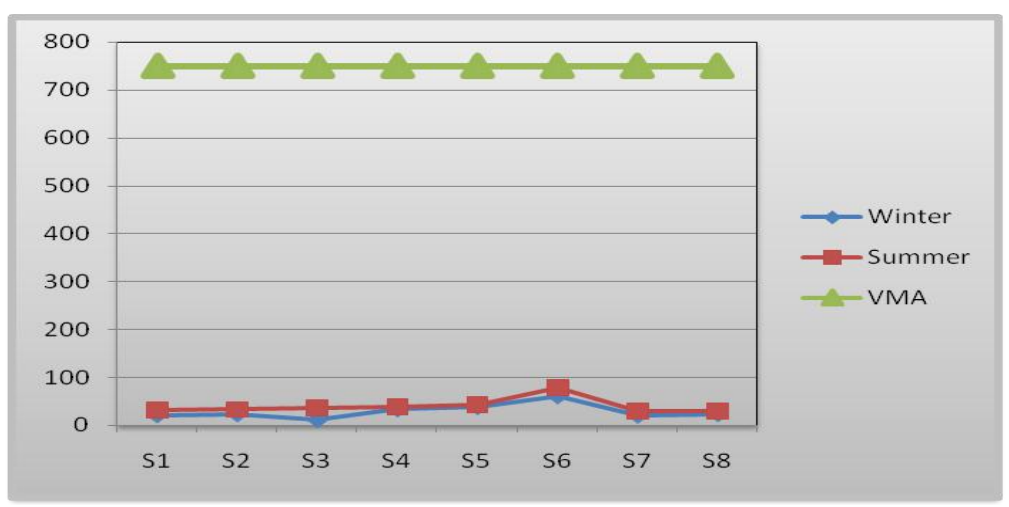

Fig 16: Variation of Chlorides according to drilling for the two months.

For the entire study period, chlorides record levels that do not exceed Moroccan standards set at $750 \mathrm{mg} / \mathrm{L}$ (El Haissoufi et al. 2011). Relating to the quality of water for human consumption. This makes it possible to classify these waters in the acceptable 
grid. However, it should be noted that the results recorded for chloride contents in the groundwater studied agree with those obtained by the author (Nechad et al. 2014).

6. Nitrates $\left(\mathrm{NO}_{3}{ }^{-}\right)$

The nitrate content in the waters of the Sidi Taibi aquifer is between $55.9 \mathrm{mg} / \mathrm{L}$ (S7) and $69.2 \mathrm{mg} / \mathrm{L}$ (S2) during the winter period and between $81.15 \mathrm{mg} / \mathrm{L}$ ( S5) and $150 \mathrm{mg} / \mathrm{L}$ (S8) in the summer period. These results recorded in nitrate ions show significant seasonal variations (Fig 17).

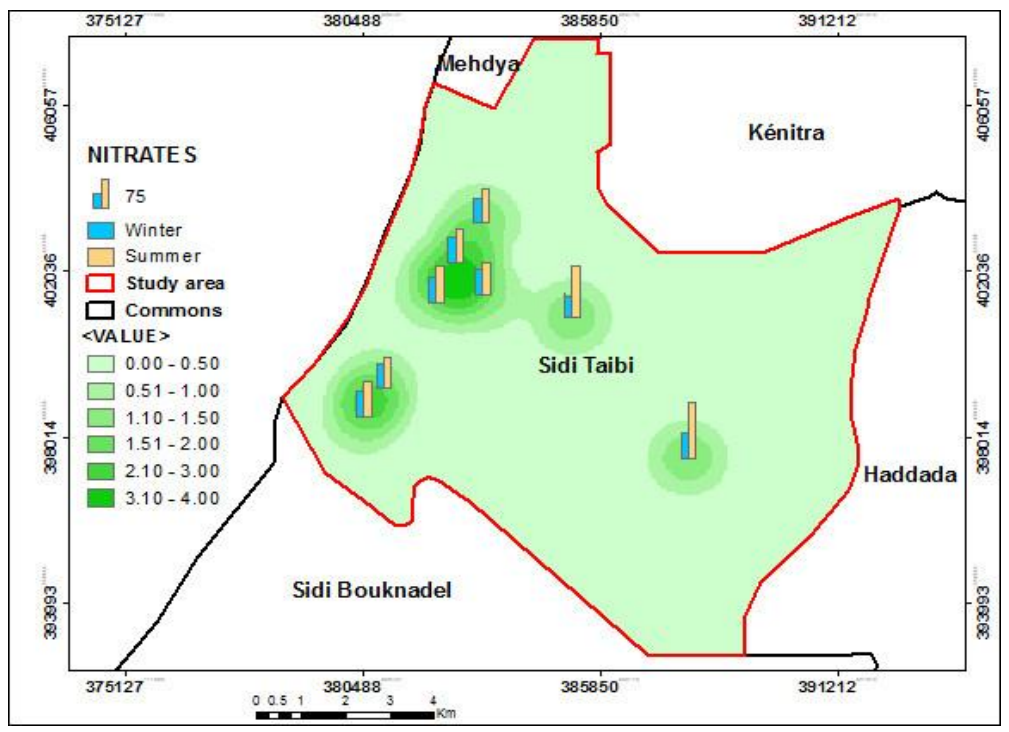

Fig 17: Variation of Nitrates as a function of drilling for the two months.

The results obtained are similar to the conclusions drawn in the case of Basse Moulouya confirming the anthropogenic origin of nitrates (Nouayti et al. 2015). The abnormal nitrate contents obtained in these waters join those obtained in the underground waters of the Sidi Kacem region (Laafou $\boldsymbol{e t}$ al. 2015). in the spring waters of the El Hajeb region (El Kharmouz, 2013). also those reported in the underground waters of the city of Oujda (Kahoul et al. 2014), and in the underground waters of El Jadida (Abbou et al. 2014). The high nitrate values are reported by other researchers who have worked on the groundwater of the city of Taza (Saâdi et al. 1999; Abbou et al. 2013). The high proportion of nitrates can be caused by the use of chemical fertilizers in agriculture. Heavy precipitation and the absence of plant cover contribute to the rapid leaching of nitrates to the Sidi Taibi aquifer (Bricha et al. 2007). The researcher (Laigle et al. 1990). has noted that the winter period constitutes the critical phase of leaching of excess nitrogen in groundwater in France in the Rhine valley. In our study, the nitrate ion results obtained in almost all of the water points tested exceed the (MAV) $50 \mathrm{mg} / \mathrm{L}$ of the Moroccan standard (Saâdi et al. 1999), and the WHO (Laafou et al. 2013), relating to the quality of drinking water. The result is that the water quality in the study area is degraded.

\section{Sulfates $\left(\mathrm{SO}_{4}{ }^{-}\right)$}

Our research area is known for high levels of sulfate concentration in our field of study. In the cold period, the sulfate concentration reaches $309 \mathrm{mg} / \mathrm{L}$ (S7). In the hot season, this concentration increases in all water points to $370 \mathrm{mg} / \mathrm{L}$ (S6). And, which is close to 
the value specified in $400 \mathrm{mg} / \mathrm{L}$ according to of the Moroccan standard measures, according to indication (Fig 18), it can be said that the results obtained show high levels of sulfate concentration with all aqueous oilBicarbonate concentrations are found at low levels in our research field, and close between the two seasons.

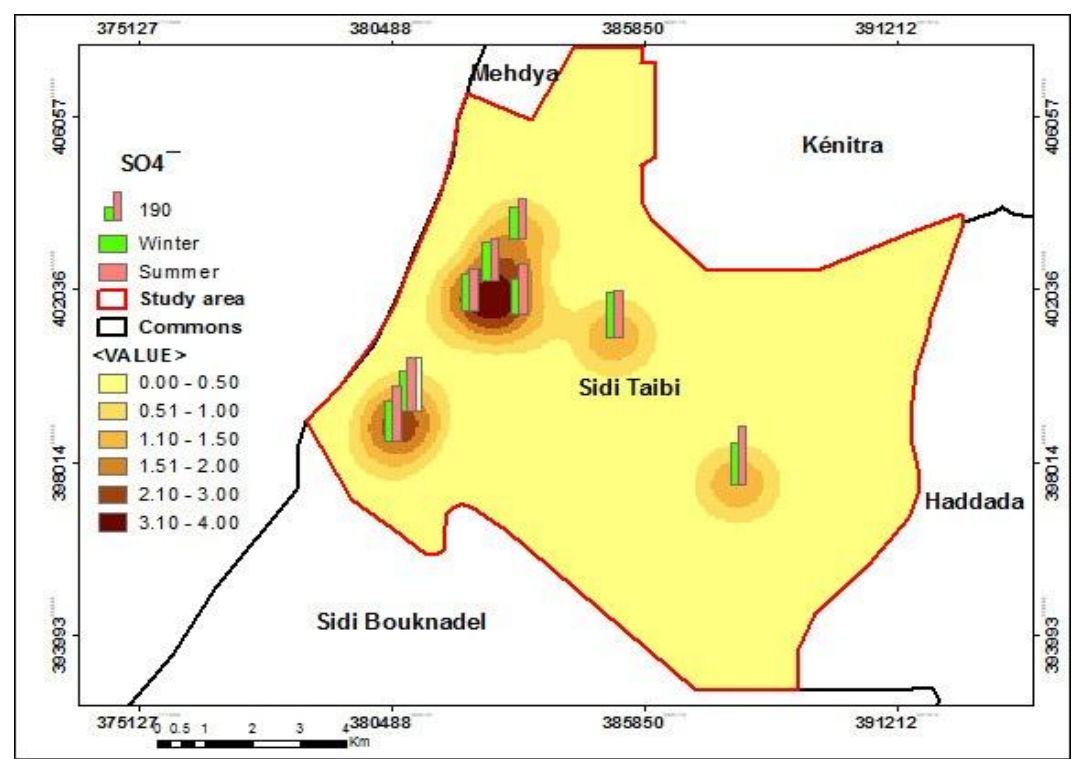

Fig 18: Variation of Sulfates as a function of drilling for the two months.

\section{Bicarbonates $\left(\mathrm{HCO}_{3}{ }^{-}\right)$}

Bicarbonate concentrations are found at low levels in our research field and close between the two seasons. Between 9,01 mg / L (S1) and $30 \mathrm{mg} / \mathrm{L}$ (S7) were recorded, As for the hot period, it does not exceed 48,02 mg / L (S8), these results recorded during the two seasons do not show significant seasonal differences (Fig 19), the levels of bicarbonate recorded in our field do not exceed $300 \mathrm{mg} / \mathrm{L}$ according to the specific Moroccan standard measures.

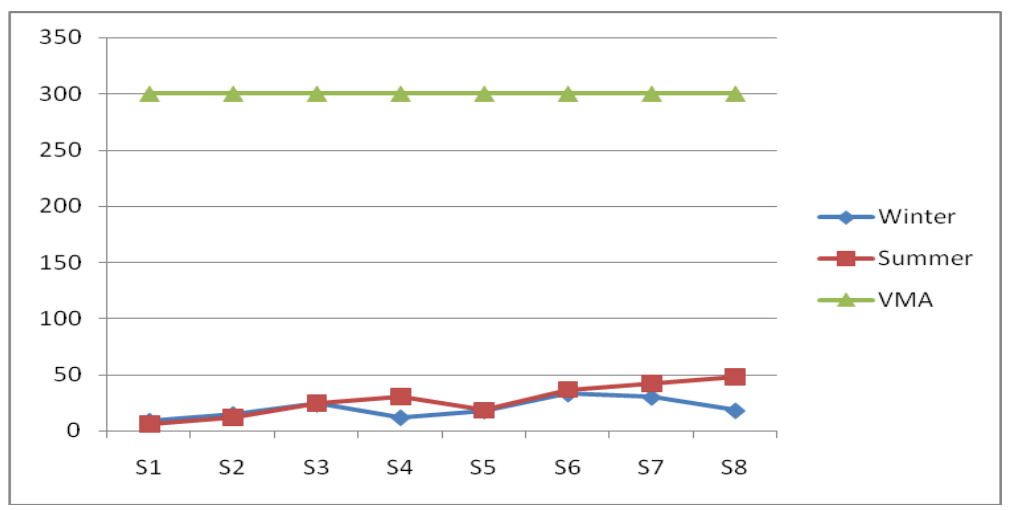

Fig 19: Variation of Bicarbonates as a function of drilling for the two months.

\section{CONCLUSION}

The study of the characterization and variability of the quality through the monitoring of different physico-chemical parameters allowed us to define the conformity of potability 
of the different parameters analyzed according to the standards of Morocco and WHO of the waters intended for human consumption during the hydrological seasons (winter and summer). The monitoring and analysis of these wells water parameters in the Sidi Taibi region, during the various sampling journeys carried out during this study, enabled us to note the non-conformity of the groundwater in the aquifer. By Sidi Taibi following the high values of the following analyzed parameters $\left(\mathrm{NO}_{3}{ }^{-} \mathrm{Na}^{+}\right)$:

-The recorded values of nitrates in $68 \%$ of the water points of sampling are exceeding the $50 \mathrm{mg} / \mathrm{L}$ standards of Morocco and WHO. This is an indication of agricultural pollution.

-The sodium values in all of the water points studied are higher than the maximum admissible value $20 \mathrm{mg} / \mathrm{L}$ of the Moroccan standard and that of the WHO relating to the quality of drinking water. In certain cases, exceeding the thresholds imposed by the WHO can have harmful effects on the health of the population consuming these waters, especially in the long term. The results of the other parameters analyzed which come into play in determining the physicochemical quality of the water in the Sidi Taibi aquifers comply with the WHO directive. The samples and the interpretation of the data show that metallic trace elements $\left(\mathrm{Fe}^{2+}, \mathrm{Mn}^{2+}, \mathrm{Ni}^{2+}, \mathrm{Cu}^{2+}, \mathrm{Zn}^{2+}\right.$, and $\left.\mathrm{Pb}\right)$ at various controlled water points remain weak to speak of heavy metal pollution.

\section{REFERENCES}

Akkaoui, O.; El Rhaouat, O.; Fraine, C.; Fareh, M.; Najy, M.; El Kharrim, K. and Belghyti, D. (2017). Note sur la qualite des eaux souterraines des sources d'Oulmes Maroc. International Journal of Innovation and Applied Studies, : 19 (2), 396.

Al-Qawati, M.; Idrissi, Y, A.; Alemad, A.; Belhaili, I.; Marc, I.; Baichouti, F.; El Kharrim, K. and Belghyti, D. (2015). Analyse et Contrôle de la qualité physicochimique des eaux souterraines De la région Sidi Allal Tazi-Gharb-Maroc. International Journal of Innovation and Applied Studies,: 13(2), 420.

Abbou, M, B.; Fadil, F.; El Haji, M. and Zemzami, M. (2014). Impact anthropique sur la qualite des eaux souterraines du bassin versant de l'oued Taza (Maroc) European Scientific Journal, ESJ, : 10(5).

Abbou, M, B.; El Haji, M.; Zemzami, M. and Fadil, F. (2013). Détermination de la qualité des eaux souterraines des nappes de la province de Taza (Maroc). Larhyss Journal : (16).

Bouabdallah, D. (2015). Analyses physico-chimiques de l'eau potable au niveau de la wilaya de Djelfa (Ville de Ain Oussera).

Bouchouata, O.; Ouadarri, H.; Abidi, A.; Benabbou, A.; El Guamri, Y.; Attarassi, B. and Brahim, J. (2012). L'accumulation des métaux lourds au niveau des cultures: cas des cultures maraîchères du bassin de Sebou au Maroc.Afrique Science: Revue Internationale des Sciences et Technologie, : 8(2).

Ben Aakame, R. (2015). Caractérisation hydro-chimique, toxicologique et évaluation des risques sanitaires des eaux souterraines de la région de Sidi-Kacem (Maroc).

Belhadj, M.; Boudoukha, A. and Mezedjri, L. (2011). Qualité des eaux de surface et leur impact sur l'environnement dans la wilaya de Skikda (Nord-est de l'Algérie). Contamination naturelle par le mercure. European Journal of Scientific Research,: 56 (2), 204-211. 
Bricha, S.; ounnine, K.; Oulkheir, S.; El haloui, N. and Attrassi, B. (2007). - Etude de la qualité physico-chimique et bactériologique de la nappe phréatique M'nasra (Maroc), Revue Afrique Science 03 : (3), 391-404.

CAWST. (Centre for Affordable Water and Sanitation Technology) (2013). Introduction à l'Analyse de Qualité de l'Eau de Boisson. Manuel, 197.

CLAUDE,C. (1999). Les traitements de l'eau. Procédés physico-chimiques et biologiques. Cours et problèmes résolus Ed. Marketing S.A. Paris.

Derwich, E.; Benziane, Z.; and Benaabidate, L. (2014). Etude de la qualite metallique des eaux souterraines situees au voisinage des eaux usees dans le bassin versant du Moyen Sebou: Maroc. Revue; LJEE.

Darwesh, N.; Allam, M.; Meng, Q.; Helfdhallah, A.; Ramzy, N.; El Kharrim, K.; Al Maliki, A and Belghyti, D. (2019). Using Piper trilinear diagrams and principal component analysis to determine variation in hydrochemical faces and understand the evolution of groundwater in Sidi Slimane Region, Morocco. Egypt. Aquat. Biol. Fish., ISSN 1110 - 6131: 23 (5): 17 - 30.

El Haissoufi, H.; Berrada, S.; Merzouki, M.; Aabouch, M.; Bennani, L.; Benlemlih, M.; Idir, M.; Zanibou, A.; Bennis,Y. and Lalami, A. (2011). Pollution des eaux de puits de certains quartiers de la ville de Fès, Maroc. Revue de Microbiologie Industrielle Sanitaire et Environnementale, 5(1), 37-68.

El Bouqdaoui, K.; Aachib, M.; Blaghen, M. and Kholtei, S. (2009). Modélisation de la pollution par les nitrates de la nappe de Berrechid, au Maroc. Afrique Science: Revue Internationale des Sciences et Technologie, 5, (1).

El Ouedghiri, K.; El Oualti, A.; El Ouchy, M.; Zerrouq, F.; Chahdi, F. and Lalami, A. (2014). Risques sanitaires liés aux composés chimiques contenus dans l'eau de boisson dans la ville de Fès: Cas des ions nitrates et nitrites (Health risks of the chemicals in drinking water in the city of Fez: nitrate and nitrite ions).

El Kharmouz, M. (2013). L'étude de l'impact des lixiviats de l'ancienne décharge publique de la ville d'Oujda (Maroc oriental) sur la qualité physicochimique des eaux souterraines et superficielles. Larhyss Journal ISSN 1112-3680 : (16).

Ibeda, A.; Abosith, M.; Alemad, A.; Elkharrim, K. and Belghyti, D. (2013). Physicochemical quality of Murzuq groundwater Sabha, Libya. WIT Transactions on Ecology and the Environment. 178: 225-239.

Kherrati, I.; A, Alemad.; Sibbari, M.; Ettayea, H.; Ezziani, K.; Saidi, Y.; Benchikh, M.; Alzwi, S.; Chiguer, H. and Zgourdah, Z. (2015). Health Risk of Maâmora's Groundwater Pollution in Morocco. Natural Resources, 6, (04), 290.

Kahoul, M.; Derbal, N.; Alioua, A. and Ayad, W. (2014). Evaluation de la qualite physico-chimique des eaux de puits dans la region de Berrahal (Algerie). Larhyss Journal ISSN 1112-3680 : (18).

Laigle, D.; Kugler, J.; Kobus, H. and Zilliox, L. (1990). Contamination des eaux souterraines par les nitrates: recherches et applications dans le cadre de la coopération franco-allemande.

Laafou, S.; Abdallaoui, A. and El abidi, A. (2013). Etude de la qualité physicochimique des eaux de certaines sources de la région d'El Hajeb. ScienceLib Editions Mersenne, Volume 5, $\mathrm{N}^{\circ}$ 130603.2013, ISSN: 2111-4706.

Lupton, S. and Bauby, P. (2008). Directives européennes sur la qualité de l'eau et montée de la délégation du service d'eau potable en France. Cosmopolitiques. 
Matthess, G.; Mijinbouw, G.; Forstner, U. et Wittmann, G. (1994). Metal pollution in the Aquatic Environement., 53: 194, 355-359.

Nouayti, N.; Khattach, D. and Hilali, M. (2015). Evaluation de la qualité physicochimique des eaux souterraines des nappes du Jurassique du haut bassin de Ziz (Haut Atlas central, Maroc). J. Mater. Environ. Sci. : 6(4), 1068-1081.

Nechad, I.; Fadil, K.; and Fadil, F. (2014). qualité physicochimique des eaux des sources Ain Regrag et Ain Sidi Bouali dans la région de Sefrou (Moyen Atlas, Maroc). Larhyss Journal . (20).

OMS. (2004). Directives des qualités pour l'eau de boisson (3ème édition). Volume 1.

Santé Canada. (2013). Recommandations pour la qualité de l'eau potable au Canada : Document technique la turbidité, Bureau de l'eau, de l'air et des changements climatiques, Direction générale de la santé environnementale et de la sécurité des consommateurs, Santé Canada, Ottawa (Ontario). ( $\mathrm{N}^{\circ}$ de catalogue H144-9/2013FPDF).

Saâdi, Z.; Maslouhi, A.; Zéraouli, M. and Gaud et, J, P. (1999). Analyse et modélisation des variations saisonnières des concentrations en nitrates dans les eaux souterraines de la nappe Mnasra, Maroc.Comptes Rendus de l'Académie des Sciences-Series IIA-Earth and Planetary Science : 329(8), 579-585.

Taouil, H.; Ahmed, S.; El Assyry, A.; Fadli, M.; N, Hajjaji. and A, Srhiri. (2014). Pollution by heavy metals of sediments of nine water sources of tyikomiyne region, watershed of guir (Eastern Morocco). Environmental Science : An Indian Journal, 9(1). 